2013

\title{
The Impact of Slack Resources on High-Tech IPOs
}

\author{
Fariss-Terry Mousa
}

Richard Reed

Cleveland State University, r.reed68@csuohio.edu

Follow this and additional works at: https://engagedscholarship.csuohio.edu/bus_facpub

Part of the Technology and Innovation Commons

How does access to this work benefit you? Let us know!

Publisher's Statement

This is the accepted version of the following article: Mousa, F., Reed, R. (2013). The Impact of Slack Resources on High-Tech IPOs. Entrepreneurship Theory and Practice, pp. 1123-1147, which has been published in final form at http://onlinelibrary.wiley.com/doi/10.1111/ etap.12001/full

\section{Original Published Citation}

Mousa, F., Reed, R. (2013). The Impact of Slack Resources on High-Tech IPOs. Entrepreneurship Theory and Practice, pp. 1123-1147.

This Article is brought to you for free and open access by the Monte Ahuja College of Business at EngagedScholarship@CSU. It has been accepted for inclusion in Business Faculty Publications by an authorized administrator of EngagedScholarship@CSU. For more information, please contact library.es@csuohio.edu. 


\section{The Impact of Slack Resources on High-Tech IPOs \\ Fariss-Terry Mousa Richard Reed}

Research on organization slack has focused mainly on its eftect in large publicly traded firms, but little work exists on the value of slack resources for other firms. Therefore, here, we address the question: Do slack resources matter in the case of initial public offerings (IPOS)? We argue that firms that possess financial, innovational, and managerial slack resources are sending a positive signal to potential investors regarding the quality of the IPO. Using a sample of high-tech IPOs, we find support for that contention.

\section{Introduction}

In established firms, it has been found that slack resources act as incentives to experiment and make proactive strategic choices (George, 2005), they are deployed to build capabilities that make firms competitive, they help maintain coalitions that ensure the convergence of personal and organizational goals, and they act as buffers in periods of economic duress (George). We argue that excess or "slack" resources possessed by firms undergoing an initial public offering (IPO) can signal the future potential of that firm and the quality of the investment. From a resource-based perspective, slack resources can provide a competitive advantage to new firms and therefore, offer a promise of superior financial performance. Because new firms have not yet demonstrated the ability to successfully handle the demands of public trading (e.g., market fuctuations), they are discounted by investors (Certo, 2003). Slack resources may compensate for this "liability of market newness" by reducing the risk of investment for the purchasers of the IPO.

The main reasons why firms undertake IPOs are twofold: needing capital to bring an invention 10 market, or the owners, or venture capitalists, wanting to be able to realize financial gains. In the case of the latter, investors will only be interested in making a financial commitment if the business has the potential for generating capital gains in stock, which, again, means bringing a viable invention to market or capitalizing on an existing invention. That requires having operational abilities, the ability to imovate or generate subsequent innovations, and managers to formulate strategy and implement

Please send correspondence to: rariss-Tery Mousa, tel: (540) 568-3237: amail: mousax (ajmu,edu and to Richard Reed at reed68 (6suohio,edu. 
supporting tactics. Therefore, this research focuses on three types of slack resources that are particularly relevant to firms that are going through an IPO. Like most work on slack, we use financial slack as an independent variable. We also develop two measures of slack that are new: innovation slack-the reason most new firms emerge-and managerial slack, which reflects Penrose's (1959) original arguments on spare management capacity and its value in promoting firm growth. By examining all three types, this work provides a more complete understanding of the effects of slack resources on young organizations.

Slack denotes the difference between a firm's current resources and the current resource demands on the firm (Mishina, Pollock, \& Porac, 2004). Slack resources provide frms with the required flexibility to develop strategic options to pursue opportunities (Greenley \& Oktemgil, 1998). They also can be diverted or redeployed to achieve organizational goals (George, 2005). Slack has been used to explain diverse organizational phenomena including performance, innovation, goal conflict, effectiveness, and political behavior, and these resources differ in both type (e.g., financial or social capital) and form (e.g., absorbed or unabsorbed). As already noted, studies of organizational slack typically have focused on large publicly traded firms, which are dealing with very different issues to nascent firms. Very little attention has been given in the literature to the effect of organizational slack on the performance of these younger firms.

In business, we usually address risk in terms of managerial risk, or income stream uncertainty (cf. Palmer \& Wiseman, 1999), but a third conceptualization of risk, which is implicit in these other definitions, is explained as probability $x$ consequence (Reed, Lemak, \& Hesser, 1997). This latter conceptualization of risk has utility in model building (Storrud-Barnes, Reed, \& Jessup, 2010). Here, probability and consequence refer to the probability of an investor losing their investment in an IPO firm. In larger, established firms, the implicit question that has always shadowed work on slack is whether or not an agency issue exists as managers try to reduce risk to their employment capital by holding slack as a cushion against a downtum in performance (e.g., Bourgeois, 1981; Nohria \& Gulati, 1995, 1996). In established firms, managers keep their jobs and stockholders keep most or all of their investment. For new firms, the issue is different. Slack resources reduce the probability that the firm will fail, which means that for a given level of return, investors will be willing to pay a premium at the time of the IPO. In new firms, not only do slack resources increase the upside potential of being able to capitalize on opportunities, they also reduce downside risk for investors.

This work contributes to the literature in several ways. First, we propose that slack resources represent important information for IPO investors; slack resources act as a quality signal. It thus provides insight into the value investors place on slack resources. Second, it provides empirical support for the conceptual framework by drawing on a rich set of IPO data in the United States during the period of 2001-2009. Third, we extend organizational slack research by moving away from well-established organizations to study the effect of slack resources in IPO firms. Finally, this study extends knowledge on organizational slack by moving beyond the traditional emphasis on financial slack to include innovational and managerial slack.

\section{Theoretical Foundations and Literature Review}

\section{Signaling Theory and IPO Firm Research}

Investors not only find it challenging to evaluate the overall quality of an IPO in terms of the potential returns that will be generated, there are also diffculties with 
assessing risk, despite the list of risks that have to be included in the published prospectuses. Assessing risk is difficult because these new-to-the-market firms may have few or no revenues, and it may be difficult to accurately value their assets. To overcome such hurdles, investors seek nontraditional methods for making assessments of IPO quality. They rely on signals that can indicate the quality of the firm (Certo, 2003). Firms that are able to signal high quality stand a better chance of raising the necessary capital through an IPO for commercialization of underlying technology and future growth (Deeds, DeCarolis, \& Coombs, 1997: Stuart, Hoang, \& Hybels, 1999). Among other things, signaling mechanisms that are used by firms include the reputations of investment bankers (Carter, Dark, \& Singh, 1998b), auditors (Beatty, 1989), and venture capitalists (Megginson \& Weiss, 1991). The fact that investment bankers avoid poor quality IPO firms to protect their reputations is evidence of the credibility of this type of signal (Certo, 2003). According to market-signaling theory, certain variables or indicators send signals to potential investors about the capabilities and, therefore, the future value of firms (Akerlof, 1970; Spence, 1973). Signaling theory is useful in situations where information asymmetry is high (Spence) because, as Akerlof showed, in instances where buyers (for IPOs, read investors) cannot determine quality, they are reluctant to buy, and markets collapse.

The literature on IPO signaling is extensive. For example, the board of directors can act as a signal to potential resource holders about the quality of a young firm (Certo, Daily, \& Dalton, 2001), especially given that investors value prestigious board structures, thus reducing the liability of newness and improving IPO firm stock performance (Certo, 2003). Pollock, Chen, Jackson, and Hambrick (2010) found that prestigious affiates (executives, directors, venture capitalists, and underwriters) communicate different signals of IPO worth. Other signals, for example, can indicate a top management team (TMT)'s ability to manage the firm (Zimmerman, 2008). Signals to investors also can be achieved through releasing information on research and development (R\&D) expenditures, the history of technological performance, or the number of products brought to the market (Deeds et al., 1997). Table 1 provides a summary of key literature on signaling in IPOs.

Ndofor and Levitas (2004, p. 688) define signaling as "the conduct and observable attributes that alter the beliefs of, or convey information to, other individuals in the market about unobservable attributes and intentions." Where Ndofor and Levitas were concened with both behavior and attributes, we are concerned only with the latter. We are concerned with investors' ability to see information on slack resources and interpret it in terms of potential for future income and amelioration of investment risk. Thus, we draw on the essential principle of signaling theory: the signal must be observable (Spence, 1973) and known in advance (Certo, Daily, et al., 200I; Janney \& Folta, 2003). Consistent with the logic of Ndofor and Levitas, firms that signal the existence of slack resources are creating a "separating equilibrium" whereby investors are able to distinguish between firms with the potential for growth and reduced risk and those that do not have the potential, or which carry higher risk. Given that money for investment in IPOs is not available in infinite amounts, and that other firms may be doing an IPO at the same time, it becomes a zero-sum game whereby one firm is likely to win at another's expense. Firms that are endowed with slack resources will therefore make a point of signaling it to investors, whereas those that do not possess the slack will be unable to make that signal.

Because resource information is included in the prospectus, slack resources are known to investors in advance of the actual offering. Financial-slack information can be gathered from a hrm's balance sheet. Information on other types of slack, such 


\begin{tabular}{|c|c|c|}
\hline Signal & How & Studies in the literature \\
\hline VC.bakking/partnerthips & $\begin{array}{l}\text { For chample, provide fonancial rescunces and } \\
\text { expentise that serve as important signals of new } \\
\text { venture qualify, }\end{array}$ & 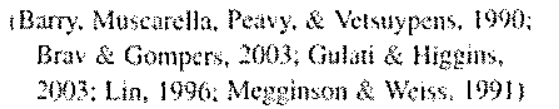 \\
\hline Auditor reputation & $\begin{array}{l}\text { The quality af the atution will sional the high } \\
\text { qualty of the } \mathrm{IPO} \text { fim }\end{array}$ & $\begin{array}{l}\text { Beaty, 1989, Daily, Certo, Dalton, \& } \\
\text { Roangpilya, 2003; Titman \& Taeman, 1986) }\end{array}$ \\
\hline Underwriter reputation & 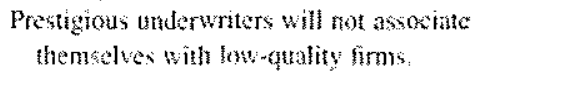 & 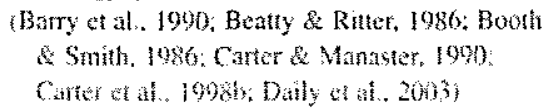 \\
\hline Strong eaming history & $\begin{array}{l}\text { A hivory of strong eamings signaly futue strong } \\
\text { perfomance. }\end{array}$ & Troh. Weleh, \& Womg, 1998) \\
\hline 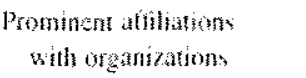 & 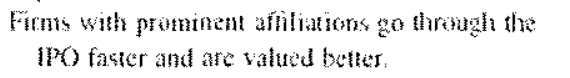 & 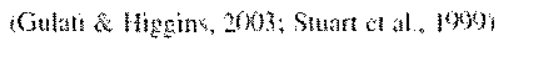 \\
\hline Lochup perial & 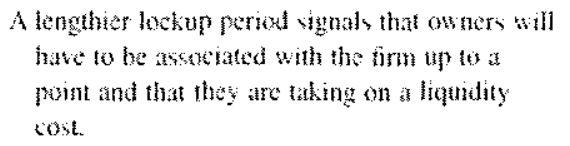 & 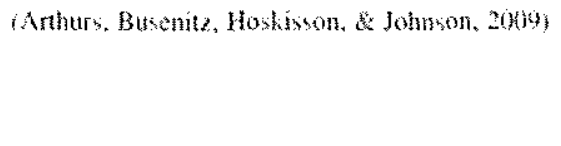 \\
\hline Fim tizs & Larger firms might have aceess to more renources. & 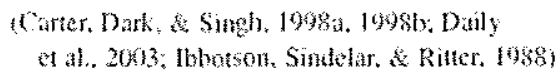 \\
\hline MT" compostion & 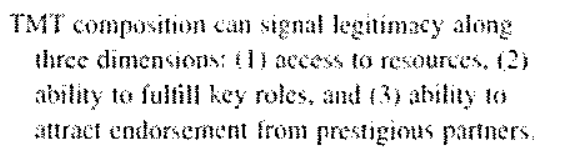 & Higgens \& Gulati. 2(W6) \\
\hline Corporate govemane & $\begin{array}{l}\text { Presigious directors could inerease firn } \\
\text { legitimacy and hence lower information } \\
\text { asymmetr. }\end{array}$ & 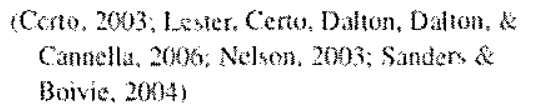 \\
\hline Equity retuinted by insiders & A signal of confldene to proppative investors. & 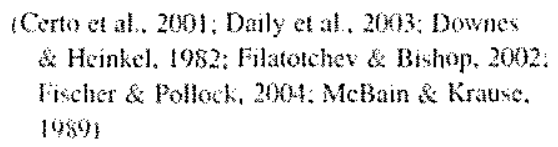 \\
\hline
\end{tabular}

as managerial and innovational slack, also can be found in the prospectus. Managerial information can be found in the management section of the prospectus. Innovationalslack information can be found both in the income statement ( $R \& D$ spending) and in the business section (patent counts).

\section{Organization Slack}

Financial Slack Researchers have used financial slack in a number of different forms as a predictor of innovation (Nohria \& Gulati, 1996), performance (Bromiley, 1991; Tan \& Peng, 2003), and the firm's ability to experiment (Wiseman \& Bromiley, 1996). Financial slack refers to the level of assets available to an organization (e.g., cash on hand) (Kraatz \& Zajac, 2001) that can easily be deployed to varied uses (Mishina et al., 2004). Financial slack is the least absorbed form of slack, especially given that it is completely divisible for the allocation of multiple activities (Greve, 2003). The existence of liquid financial resources in a firm indicates that the firm has resources in excess of what is required to meet current obligations and support current sales levels (Mishina et al.). Financial 
resources can be generated internally or externally. Internal resources are composed mainly of the profits from a firm's present investments. Those raised externally are acquired through capital markets or financial institutions and can be used for future investment. These fnancial resources can be used to purchase equipment, employ scientists, build new laboratories, invest in new buildings, hire sales people, invest in R\&D, and improve marketing. Financial resources thus offer to firms a high level of transferability to profit-yielding activities (Amit \& Schoemaker, 1993). Although financial resources are not rare or unique, they are essential and do offer a competitive advantage to firms that possess them (Latham \& Braun, 2008). Their existence in new firms can lead to superior financial performance and, thus, better IPO valuations.

Some scholars have argued that slack may be advantageous only up to a certain point (Bourgeois, 1981: Nohria \& Gulati, 1995, 1996; Tan \& Peng, 2003) because Bourgeois's original thinking on the topic linked organizational inefficiency to slack. He argued that inefficiency is a natural outcome of high levels of slack within an organization. This may be true in well-established, publicly traded firms. We argue that IPO firms do not have the luxury of being seen as inefficient, given the high scrutiny they face when going public. However, firm valuation may depend on whether a firm will have the resources necessary to successfully navigate the IPO process. In this case, slack would ease capital restrictions and improve the strategic choices of managers for investments with positive performance implications (George, 2005). Also, it allows hexibility and experimentation, which can have positive performance effects (George). Bourgeois further suggested that slack gives decision makers the freedom to make decisions with little information, and that, when necessary, it may give an organization the time needed to collect additional information. In view of these arguments, we propose that higher levels of financial slack are positively related to fim valuation at IPO. "The higher the level of mancial slack, the stronger and more apparent is the quality signal to investors.

Using precedent (e.g., Mishina et al., 2004; Voss, Sirdeshmukh, \& Voss, 2008), and building on the view that slack resources should be considered as excess resources rather than just total resources (Moses, 1992), we explore the effects of two different types of financial slack (cash reserves and working capital). Cash reserves represent the level of available cash (cash on hand) to an organization (Kraatz \& Zajac, 2001). For investors, slack resources in the form of cash, which is the nearest of financial resources and the most fungible, sends a strong signal. If the firm has sales, then it signals upside potential in the form of positive cash flow and an ability to generate more cash. In terms of the downside, regardless of whether or not the firm has sales, it signals protection against failure and bankruptcy. The more cash a firm has, then the more positive the signal. Working capital is different. It is the difference between current assets and current liabilities, and it captures the use of current resources relative to activity (Bourgeois \& Singh, 1983). It portrays information on the assets required to maintain day-to-day operations, and includes things like inventory needed for operations and excess of accounts receivable over accounts payable, again, relative to the level of activity (Moses). Working capital is a resource that is neither a near resource (easily turned into cash). particularly in young firms without the leverage to collect bills or with inventory of a new or unproven technology, nor is it particularly fungible. That means that the greater the amount of working capial required to maintain day-to-day operations, the greater the nsk for investors. Firms that can operate with less working capital should be able to attract an investment premium over those that require more working capital.

Details on approaches used to measure cash reserves and working capital are described in the Methods section. In the interim, it can be stated that: 
Hypothesis 1a: There is a positive linear relationship between cash reserves and IPO valuation.

Hypothesis 1b: There is a negative linear relationship between working capital and IPO valuation.

Innovational Slack. Our interest lies specifically with the slack useful for generating innovations, which will be called in this paper "innovational slack." Innovational slack refers to the stock of resources available to an organization such as underused R\&D facilities, specialized development staff, and time for development activities. Managers can allocate a certain amount of time for product developers to work on their own projects and loosen performance standards for new projects (Jelinek \& Schoonhoven, 1990). Overall, then, innovational slack can be viewed as a refinement to existing organizational-slack theory. In this work, we view innovational slack as excess unused intellectual property and above-industry-average $R \& D$ spending. We suggest that firms may have two different types of innovational slack: inputs into the innovation process (e.g.. R\&D) and outputs (e.g. patents). Both can be used to create more innovations through the application of new knowledge or by combining them with other knowledge.

Proponents of slack argue that organizational slack plays a vital role in allowing innovation (Nohria \& Gulati, 1995). Slack permits firms to more safely experiment with new strategies and innovative projects that most probably would not be approved in a more resource-constrained enviromment (Cyert \& March, 1963/1992). Other researchers counter this argument, suggesting that slack diminishes incentives to innovate and promotes undisciplined investment in R\&D activities that rarely yield economic benefits (Leibenstein, 1969). To reconcile these differences, Nohria and Gulati $(1995,1996)$ hypothesized and demonstrated that the actual relationship between slack and innovation is curvilinear (an inverse U-shape). Per that inverted-U argument on slack, it can be argued that too much slack before the IPO implies that such firms will face diminishing discipline. As slack increases, the discipline that is exercised in the selection, ongoing support. and termination of projects becomes lax (Jensen, 1993; Leibenstein; Nohria \& Gulati, 1996). For example, over time, and with increasing slack, risky projects with negative net present value may be funded simply because the resources exist to indulge agents for whom these are pet projects (Nohria \& Gulati). Escalation of commitment also becomes an issue given that excess levels of slack make it difficult to terminate someone's pet project (Staw, Sandelands, \& Dutton, 1981). Therefore, it can be argued that innovational slack fosters an X-inefficient (Leibenstein, 1966) atmosphere around resource allocation that increases both the risk that poor projects will be continued even in the face of negative information and that projects will be abandoned simply because someone ran out of energy, became bored, or ran into a tough problem (Nohria \& Gulati, 1996). Based on these arguments we propose that innovational slack would have a positive effect on IPO valuations up to a certain point, but, after that point, slack can indicate future inefficiency and will have a negative effect.

The relative amount of $R \& D$ spending has been used as an indicator of innovative activity (Scherer, 1980), and a number of studies have considered the relationship between R\&D spending, productivity returns, and firm performance (Comanor, 1965; Grabowski \& Vernon, 1990; Graves \& Langowitz, 1993). As the majority of the work in this area notes, there are strong industry norms associated with $R \& D$ spending. We therefore hypothesize that, relative to the industry, R\&D spending will be associated with gains in IPO value but, after a certain point, investors will interpret the spending as indicative of inefficiency, and the effect will be negative. 
Patents also are widely used as indicators of innovation activity and essential technology positions (Deeds et al., 1997, p. 37), and are widely accepted measures used by policy makers, analysts (Van der Eerden \& Saelens, 1991), and researchers (Deeds et al.). Patents provide inventors with protection in the form of a finite-life monopoly for their intellectual property. Governments are willing to issue patents to inventors in return for the greater good to society or economic progress, but issuing patents is an effective way to remove barriers to information asymmetry. As Long (2002) indicated, a downside to providing the information in a patent means that competitors may be able to quickly circumvent critical aspects of an invention and effectively appropriate some of the patentee's rents. The solution to that problem is to patent and protect information for core markets and related technologies by creating impenetrable patent fences, which allow the patent holder to exploit a technology and appropriate returns by blocking existing and new competitors (Reitzig, 2004). The creation of fences involves what is referred to as patent rafting or bulking, which simply means that a large number of patents are created around the core technology and related technologies. The process can be expensive. Firms not only have to apply for the patents but also have to maintain the patents through renewal, up to three times during the life of the patent in the United States, with increasing fees for each renewal (Malewicki \& Sivakumar, 2004). After the patents have been issued, they then have to be defended against infringement (Long). As explained by Grady, Alexander, Martin, and Merges (1992), to make defense worthwhile, the benefits of protecting the technology have to be significant. In addition to the costs of application and renewal, there are also the costs of time (patent-infringement monitoring), legal costs, and emotional and time costs of defense. As Somaya (2003, p. 24) explained in his research on patent litigation in the computers and research-medicine industries, defense can be expensive, not only in terms of direct legal costs but also because it absorbs "the time of key managers, lawyers, engineers, and scientists in the company." As the number of patents held increases, so too do defense costs. Like research and development (R\&D) spending, we predict that the relationship between patenting and IPO value will be an inverted-U shape with firms preferring mid levels of patent slack.

Eypothesis 2a: There is an inverted U-shaped relationship between R\&D slack and IPO valuation, with the best IPO valuations occurring at an intermediate level of R\&D slack.

Hypothesis 2b: There is an inverted U-shaped relationship between patent slack and IPO valuation, with the best IPO valuations occurring at intermediate levels of patent slack.

Managerial Slack. After IPO, the top management team must learn to deal with reduced flexibility in managerial discretion, increased oversight from the firm "s board of directors and blockholders, greater demands from investors for short-term performance, and less tolerance of negative press and performance volatility (PriceWaterhouse, 1995). The TMT must deal with significant cultural changes, as well as change resulting from its employees' new-found wealth as options are exercised and stock is sold, which can lead to some employees leaving the company and some others become less willing to make the personal sacrifices that were required to get the firm to the IPO stage (Fischer \& Pollock, 2004). All of this means that executives are managing the upheaval caused by the IPO while trying to manage growth and plan for the future. Penrose (1959) recognized the importance of managerial slack as an essential factor in firm growth. She observed that firms are able to grow and develop only when excess "managerial services" are released to allow managers to plan and direct growth. She also pointed out that newer firms are 
faced with numerous difficulties and that focusing on growth while managing those difficulties is extremely challenging (Penrose). The notion of having above-average managerial resources and experience at the time of the IPO is our conceptualization of managerial slack. That means not only having a sufficient number of managers but also having managers with industry experience. Managers' experience with firm-level resources produces firm-specific knowledge about the productive opportunities available to the firm (Penrose). Penrose further observed that this experience-based knowledge is proprietary because it cannot rapidly be transferred to new managers, nor can it be purchased in the market. She also emphasized that managers cannot function well as a team without firm-specific, shared experience in the TMT, which leads to the creation of tacit knowledge. In short, managerial expertise is a resource that is valuable, rare, and difficult to imitate.

Along with Penrose (1959), other researchers have argued that managers play a vital role in choosing a firm's direction. the markets it will participate in, and the blend of resources it will deploy and nurture (Castanias \& Helfat, 1991; Kor \& Mahoney, 2000; Mahoney \& Pandian, 1992). An important insight from the resource-based view shows that to generate superior returns, a firm must not only possess unique resources but also effectively and innovatively manage such resources (Mahoney, 1995). In particular, the bundle of managerial experiences can reflect the TMT's skills, knowledge, and competencies (Carpenter, Sanders, \& Gregersen, 2001; Harris \& Helfat, 1997). To assess managerial competence at the upper ranks, an examination of the bundle of experiences in the TMT is essential, especially because professional management experience molds the knowledge, confidence, and imagination of mangers (Penrose; Van de Ven. Hudson, \& Schroeder, 1984).

Clearly, managers as a resource are crucial for survival and success. On the one the hand, with too few managers, the probability of failure increases. On the other hand, too many managers also create problems. Too many managers not only raises costs in terms of managerial salaries, benefits, and perquisites, but it will also likely lead to a proliferation of organizational policies, procedures, and red tape as managers justify their existence and salaries. Again, in Leibenstein's $(1966,1969)$ terms, firms with too many managers suffer from $X$-inefficiency. Thus, in terms of managerial slack, we postulate that Nohria and Gulati's (1995, 1996) curvilinear view of slack will hold. We also postulate that it applies to our second measure of slack: managers' industry experience. Experience slack is aimed at capturing the managerial knowledge of the opportunities, threats, competition, and technologies (Kor, 2003) of an industry that also is important for survival and success. Several studies have shown that a significant amount of commonality characterizes the perceptions of managers operating within the same industry. In particular, strategic and environmental information drawn from intra-industry sources bear a marked similarity to top managers' own knowledge and perceptions of the environment and opportunities within it. Spender (1989), labeling these common views "shared recipes," suggested that they emerge as a function of managers" similar experiences amassed through industry tenure. Earlier, Hambrick (1982) had noted a comparable homogeneity in views fostered by top managers' reliance on common sources of industry information. Industry-specific experience helps top managers intensify their knowledge of competitive conditions and specific technologies in the industry. However, as that knowledge increases, it can change from being a valuable resource to being a core rigidity as managers fall prey to the insidious nature of dominant logic (Prahalad \& Bettis, 1986). Thus, too little industry knowledge can be a bad thing, as can too much.

Traditionally, the TMT has been defined as top-level executives such as the chief executive officer (CEO), chief operating officer, business unit heads, and vice presidents 
(Carpenter et al., 2001; Finkelstein \& Hambrick, 1996). Specifically in the IPO literature, researchers have considered all inside executives listed in the prospectus as key management personnel (e.g., Kor, 2003). This work follows that convention when assessing managerial slack.

Hypothesis 3a: There is an inverted U-shaped relationship between the number of insiders' slack and the IPO value, with the best IPO valuations occurring at an intermediate level of number of insiders' slack.

Hypothesis 3b: There is an inverted U-shaped relationship between insiders' industry experience slack and IPO value, with the best IPO valuations occurring at an intermediate level of industry experience slack.

\section{Methods}

\section{Sample}

To test the hypotheses, we developed a sample from all U.S. high-tech firms that had undertaken an IPO between 2001 and 2009. High-tech firms were selected to allow us to more easily test the hypothesis on innovational slack. Based on Standard Industrial Classification (SIC) codes, firms were identified as operating in high-technology sectors (Daily, Certo, \& Dalton, 2005). High-technology firms are defined as those in SIC codes 28 (biotechnology and drugs), 35 (computer and related), 38 (medical equipment), 73 (software), 36 (electronics and communication), and 48 (telephone equipment and communications services) (Carpenter \& Petersen, 2002; Loughran \& Ritter, 2004). Consistent with prior research in the field, holding companies, financial institutions, and real estate investment trusts were excluded from the sample (e.g., Fischer \& Pollock, 2004). The data were collected from the prospectuses found on the Securities and Exchange Commission Electronic Data Gathering and Retrieval system for IPOs. The final sample included 299 firms.

\section{Measures}

Dependent Variable. IPO value, which is also known as IPO proceeds raised, represents the capital raised and transferred to the firm and its owners at IPO. It is measured as the total value of the capital raised (the offer price $x$ the number of shares sold in the offering) minus the underwriters' fees as presented on the cover page of the firm's prospectus (Deeds et al., 1997; Finkle. 1998; Gulati \& Higgins, 2003: Zimmerman, 2008). The importance of a venture being able to issue an IPO is extremely important because it captures the amount of capital that an IPO firm can truly use (Deeds et al.). Therefore, the point at which these ventures decide to undergo an IPO represents a rare opportunity to measure their performance up to that point (DeCarolis \& Deeds, 1999). Certo. Holcomb, and Holmes (2009) have further suggested that this measure is both a measure of firm IPO performance (Gulati \& Higgins; Zimmerman) and a measure of how the market values a company at the time of the initial offering (Deeds, Mang, \& Frandsen, 2004; Finkle).

Independent Variables. There is considerable variety in industry context in the sample, and it is possible that slack may differ across industries (George, 2005). For instance, 
Miller, Lant, Milliken, and Kom (1996) illustrated that slack correlates differently with performance in the furniture versus software industries. And because slack is operationally defined as excess absolute levels of resources (Nohria \& Gulati, 1996), we chose to calculate slack as the deviation from the mean of each of the six industries in the sample (e.g., George). In IPO research, care is taken to ensure that sample firms are compared with representative sets. Purnanandam and Swaminathan (2004) and Brau, Brown, and Osteryoung (2004) compared their samples of IPO firms with industry "peers," while Arend (2003) did a dyadic comparison of IPOs with other within-industry IPOs, and MacGregor, Slovic, Dreman, and Berry (2000) split their sample around intra-industry IPO means. Given that we include all IPO firms within our selected industries, we have calculated slack as the deviation from the within-industry, IPO-firm mean.

We also need to note that financial ratios that are widely used in the literature may differ from one industry to another. Ratios that are the norm in one industry could be extraordinarily high or low in another industry, and thus slack measures may not generalize across industries (Miller \& Leiblein, 1996). Lev (1969) argued that average industry financial ratios offer reasonable proxies for target levels. Therefore, we measured all slack resources as the difference of a firm's own measures (e.g., accounting ratios) and its industry average. We only utilized firms in our sample to create the industry averages given the uniqueness of IPOS. We believe that the closest comparable group with any IPO firm would be similar firms that are in the same industry that also are in the process of going public.

Cash resenves represent the level of available cash (cash on hand) to an organization (Kraatz \& Zajac, 2001). These are available for deployment for virtually any purpose. This measure of financial slack is consistent with those adopted in other studies (e.g., George, 2005; Miller \& Leiblein, 1996; Voss et al., 2008). Firm cash slack was calculated using the following:

$$
\text { Cash } s \text { lack }=(\text { firm cash reserves })-(\text { average industry cash reserves })
$$

As already noted, working capital was chosen because it has been identified by scholars as an appropriate and useful operationalization of financial slack, given that it considers the (appropriate) level of working capital to meet current needs (Mishina et al.. 2004: Moses, 1992). Working capital is calculated by taking the difference between a firm's current assets (e.g., cash and cash equivalents, accounts receivable, inventory, and marketable securities) and a firm's current liabilities (e.g., accounts payable and accrued expenses) (Brealey \& Myers, 1996). The amount that is left after subtracting current liabilities from current assets is a measure of short-term financial resource utilization (Bromiley, 1991; March \& Shapira, 1987). We measured it as follows:

Working capital slack $=($ firm working capital $)-($ average industry working capital $)$.

These measures are also similar to the conceptualization advanced by Singh (1986) in regard to the two-component concept of slack where he measured absorbed and unabsorbed slack using cash and working capital. There are, of course, several measures of financial slack such as the three-component-based concept developed by Bourgeois and Singh (1983) where slack was measured using available slack (which might be equated to, say, cash), potential slack (a firm's equity-to-debt ratio), and recoverable (or absorbed) slack (which was measured using selling, general and administrative expenses divided by firm sales) (Bromiley, 1991). We chose not to calculate slack with three components (e.g., Bromiley) given the difficulty in reliably using ratios such as equity to debt for firms 
that are going through an IPO. The debt to equity calculation does not work because, of course, the equity is arriving via the dependent variable, IPO value. Also, most of these young high-tech firms possibly will have little or no equity while having a lot of debt. Additionally, the equity structure might not really be well-known at the point of IPO.

Both R\&D spending (input flows to the innovation process) and patents (stocks of output of research) are indicators of firm innovation. Traditionally, the relative amount of R\&D spending has been used as an indicator of innovative activity (Scherer, 1980). All else being equal, if firms spend more on R\&D than the industry average, there is a higher probability of them having slack intellectual property than if they spent less than the industry average. This variable is based on the R\&D-intensity variable that typically has been calculated as the level of investments divided by the firm's sales, assets, or number of employees (e.g., Deeds, DeCarolis, \& Coombs, 1998; Eulie, 1998). In this study, R\&D investments are standardized by total assets because many IPO firms do not have sales because they are still in the early years of product development (Deeds et al.; Kor, 2006). We used the last audited year of R\&D spending as provided in the prospectus of the IPO firm.

$$
\begin{aligned}
\mathrm{R} \& \mathrm{D} \text { investment slack }= & (\text { firm } \mathrm{R} \& \mathrm{D} / \text { firm assets })-(\text { average industry } \mathrm{R} \& \mathrm{D} / \\
& \text { average industry assets }) .
\end{aligned}
$$

The second innovational-slack measure is paten intensity slack. Patents are considered indicators of vital technology positions and innovative activity (Ashton \& Sen, 1988). According to Deeds et al. (1998), a fm's patent stock is an indication of the size of a firm's stock of intellectual property, and thus research productivity. Patent intensity slack was measured using the following equation:

$$
\begin{aligned}
\text { Patent intensity slack = } & \text { (number of firm patents/fim assets) - } \\
& \text { (average industry patents/average industry assets). }
\end{aligned}
$$

Managerial slack was defined earlier in the study as those excess managerial skills and experiences that help the firm to grow and, also as previously noted, in the IPO literature, researchers have considered all inside executives listed in the prospectus as key management personnel (e.g., Kor, 2003). Therefore, this work also uses the number of all insiders:

$$
\begin{aligned}
\text { Insider slack }= & \text { (number of firm TMT/firm assets) - } \\
& \text { (average industry TMT/average industry assets). }
\end{aligned}
$$

To capture a different dimension of managerial slack, we measured experience slack-the industry experience of the TMT. Based on Kor (2003), we measured this variable as the average number of managerial positions held in the same industry by managers in the firm compared with the average industry TMT positions held. This measure captures the breadth of industry-specific experience possessed by the managers (Kor), and similar to the first measure. it assumes that firms with more managers with industry experience will have more experience slack to draw upon. Also, because the size of TMTs differ from one company to the other, taking the number of positions held relative to the average number of the TMT will control for the size of the firm. Thus:

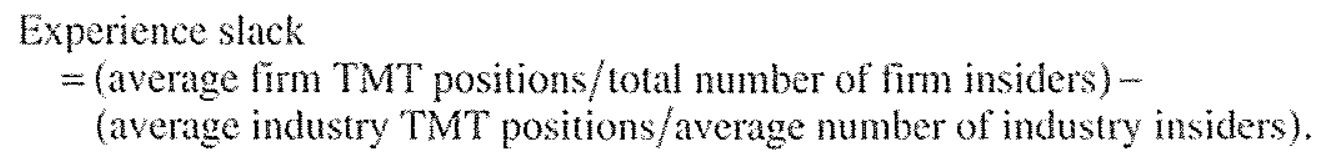




\section{Control Variables}

Per the precedent established in other IPO studies, we controlled for firm age (e.g., Beatty, 1989; Beatty \& Zajac, 1994; Finkle, 1998), which we measured as years from founding (e.g., Zimmerman, 2008). It was employed as a control variable in this work because older firms, both prior to and following the IPO, have been found to financially outperform younger firms (Certo, Covin, Daily, \& Dalton, 2001; Ritter, 1998). Also, firms with longer track records are known to have a greater chance of survival (e.g., Fischer \& Pollock, 2004). The reputation of the underwriter can impact investors' perceptions of IPO firm quality (Beatty \& Ritter; Carter et al., 1998b; Carter \& Manaster, 1990). We coded this variable from Jay Ritter's personal website at the University of Florida (where all underwriter reputation rankings are available) and it is based on the methodology employed by Carter and Manaster and Carter, Dark, and Singh. We also controlled for founder effects because founders may affect the survival and performance of new ventures (Certo, Covin, et al., 2001: Nelson, 2003). We used a dummy variable to operationalize founder on the board $(1=$ founder, $0=$ nonfounder) (e.g., Arthurs et al., 2009). Number of risk factors are included because higher risk may increase underpricing and could influence performance. Certo, Covin, et al. (2001, p. 650) write that "risk factors associated with a firm can affect both performance expectations and realized performance." Therefore, a firm's risk position was operationalized as the number of risk factors as reported in the prospectus (Beatty \& Zajac; Welbourne \& Andrews, 1996).

Equity raised or the percentage of equity offered in the IPO was measured as the ratio of total shares offered to total shares outstanding (Mudambi \& Zimmerman, 2005). It is important to control for this variable since the amount of capital raised at IPO might be a function of the percentage of equity the company floats at IPO (Zimmerman, 2008). Serial founder counted the number of other firms founded by TMT members as listed in the prospectus. IPO firms that had one or more top managers with experience in founding other companies were coded " 1 ," while firms without such experience were coded " 0 ." Typically, venture capitalists have a very positive outlook toward previous experience in founding other firms (Wright, Robbie, \& Ennew, 1997).

A high volume of IPO activity usually characterizes hot markets (Ibbotson \& Jaffe, 1975). During such a period, the number of firms that undergo an IPO and the average value of the IPOs brought to market is considerably higher than during a normal period (DeCarolis \& Deeds, 1999; Ritter, 1989). Our data showed that 2004, 2005, 2006, and 2007 all had the characteristics of a hot market. IPOs during the hot market years were coded "1," while all others were coded "0."

Generated slack generally denotes available resources for developing strategy options for future flexibility and was measured as sales per employee (Chakravarthy, 1986). More specifically, this ratio refers to the ability to attain surplus revenue from employees, and therefore the higher the ratio, the higher the resources available for future flexibility (Greenley \& Oktemgil, 1998). Invested slack was measured using R\&D by sales ratio (Chakravarthy) and generally represents deployed resources, which could reduce the opportunity to develop strategy options for future flexibility. We controlled for both of these slack measures given that some previous research has shown that excellent firms are better at managing their slack resources (Chakravarthy) and that some slack studies found a positive relationship between slack and performance (e.g., Bromiley, 1991; Miller \& Leiblein, 1996).

We controlled for prior sales. If a firm has sales, then investors consider a firm's revenue track record before the IPO (Zimmerman, 2008). Prior sales were measured using the total revenue as reported in the prospectus in each firm's income statement. This 
measure could also impact the amount of slack a firm has for a particular year given that the budgeting process will depend, in part, on prior sales. We also controlled for the possible effects of venture-capital backing (VC-backing) (e.g., Certo, Daily, et al., 2001; Megginson \& Weiss, 1991). This variable has shown to infuence the ability of an IPO firm to raise capital (Brav \& Gompers, 2003; Gulati \& Higgins, 2003; Megginson \& Weiss), increase chances of survival (Khurshed, 2000), and influence the amount of slack resources a firm has (Macmillan. Kulow, \& Khoylian, 1989). Firms backed by venture capitalists were calculated as a dichotomous measure coded 1 for VC-backing, 0 if not. Retum on assets (ROA) was measured in the year prior to IPO (Michaely \& Shaw, 1994). We controlled for ROA given that profitability is an "obvious determinant" of firms" slack resources (Chakravarthy, 1986). We controlled for fim size given that prior research has shown that larger IPO firms tend to outperform smaller ones in terms of stock appreciation (e.g., Megginson \& Weiss; Mikkelson, Partch, \& Shah, 1997). We used log of employees to control for size (e.g., Deeds et al., 1997). Finally, we controlled for private financing that IPO firms had received before going public to control for previous success in securing financial capital (e.g., Gulati \& Higgins; Stuart \& Sorenson, 2003).'

\section{Results}

We used partial hierarchical multiple regression to examine the hypotheses. Table 2 presents the descriptive statistics and correlation matrix for all variables. Overall, the correlations are low to intermediate. Patent slack is positively correlated with R\&D slack, a result that is not surprising because any firm that invests heavily in research would also want to protect any innovations that might be found during the process. Thus, it is logical that as the commitment to R\&D increases, so would the number of patents owned by the firm. The number-of-managers slack is negatively correlated with firm size in our dataset and positively correlated to cash slack, suggesting that a control for firm size is important for measuring the effect of managerial slack and financial slack. Patent and R\&D slack also were positively correlated to managerial slack. However, because the variance inflation factors (VIF) for these terms are below 3.4 , which is well below the VIF of 10 that Kennedy advocates is indicative of "harmful collinearity" (Kennedy, 1992, p. 183), it is unlikely that this correlation will confound the results of any statistical tests. We examined the VIF for all models; none were close to the commonly accepted threshold of 10 (Cryer \& Miller, 1991: Neter, Wasserman, \& Kutner, 1985). The VIF values ruled out the possibility that multicollinearity and the instability of $b$ and beta were a serious problem.

Table 3 displays the results for the regressions. The base model had five significant results: serial founder, prior sales, VC backing, firm size. and private financing. Prior sales, firm size, and private financing all had a positive relationship with IPO value, while serial founder and $V C$ backing had a negative one. Model 2 shows that the additional variables contribute significantly to ou understanding of the amount of capital raised through IPO beyond the control variables (change in $\mathrm{R}^{2}=0.335$ ). Cash reserves was positively and significantly related to the size of the IPO valuation while working capital was negatively and significanty related to IPO valuation, thus providing strong support for hypotheses la and $1 \mathrm{~b}$.

1. We wixh to thank the anonymous reviewers for this suggestion, and for other valuable insights.

2. The VIF is computed as $1 /(1-\mathrm{r} 2)$. 


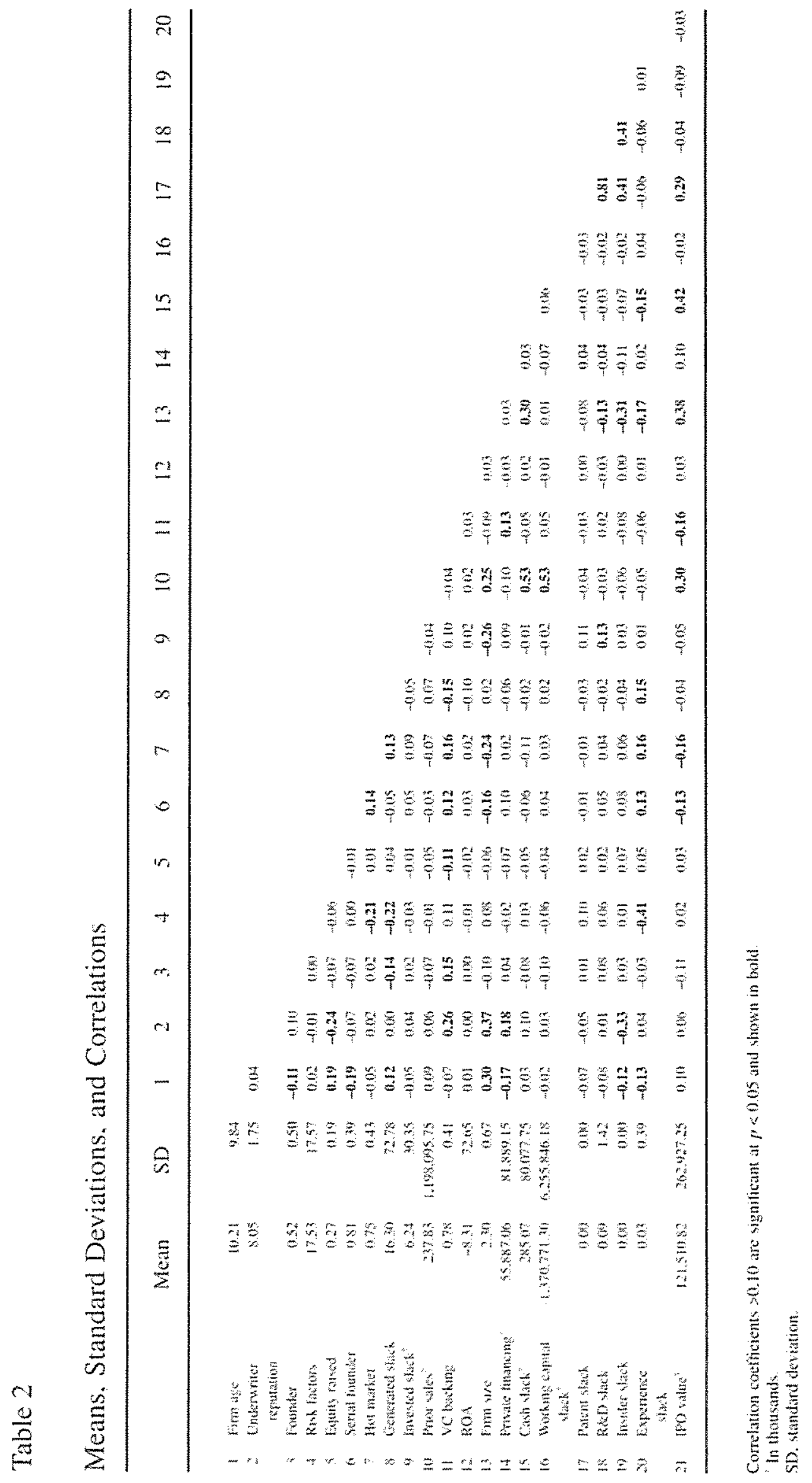


Table 3

Results of Partial Hierarchical Regression Analysis on IPO Value

\begin{tabular}{|c|c|c|c|}
\hline Dependent variable: IPO value & Model 1 & Model 2 & Model 3 \\
\hline \multicolumn{4}{|l|}{ Contrit varibles } \\
\hline Firm anes & 0,0021 & 0016 & $0.083^{2}$ \\
\hline Untenwriter reputatisn & -0.057 & .0013 & $-0.68 \%$ \\
\hline Fountets & -0075 & -0.022 & $-0.031 \%$ \\
\hline Rint Rators & -0011 & $-0,037$ & mons \\
\hline Equily ratsed & 0.052 & 0.048 & -9017 \\
\hline Serit founder & $-0.093^{*}$ & $-0,020$ & 0009 \\
\hline Hot mathe? & - (1) & -0.013 & $-001 \times$ \\
\hline Gentonted stax & $\operatorname{mon} x_{3}$ & -0156 & -0069 \\
\hline lmestot slact & 0.039 & ong & .0018 \\
\hline Erior sates & 0.237 管素 & $0.183^{*}$ & 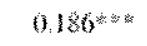 \\
\hline VC betking & -06s: & 0.043 & 0033 \\
\hline $\mathrm{ROA}$ & 0.025 & -0.008 & 0010 \\
\hline Finn sige & $0.312 \%$ & 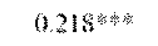 & $0,06 \mathrm{t}$ \\
\hline Privale finaning & $0.169^{\circ}$ & 0,030 & 0.033 \\
\hline \multicolumn{4}{|l|}{ Wanchects } \\
\hline Canstack & & 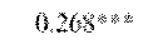 & 0,306 \\
\hline Working cepitst stack & & -0.116 & -0.151 然安 \\
\hline Patent slack & & 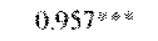 & 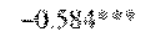 \\
\hline RED slack & & $-9.912 \%$ & -10.122 \\
\hline Insider stack & & 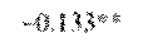 & 4.3455 \\
\hline Int experiente thack & & 007 & 0.028 \\
\hline Patent slack squared & & & 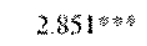 \\
\hline ReD slack squared & & & -2.019 然等 \\
\hline Insider slack saluared & & & 0.235 \\
\hline Int experituce satk sequed & & & -0.003 \\
\hline $\mathrm{R}^{3}$ & 0.253 & 0.588 & 0.736 \\
\hline Adjusted $R^{2}$ & 0.216 & 0.558 & 0.713 \\
\hline Fosfatistic & $6.858^{2}=$ & $19.8 * 5=0=$ & $31.779 \%$ \\
\hline$\Delta \mathrm{R}^{3}$ & 0.253 & 0.335 & 0.148 \\
\hline Fstatistic for change & $6.8588^{2}$ & 37.730 年为 & $38.255 \%$ \\
\hline
\end{tabular}

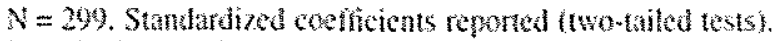

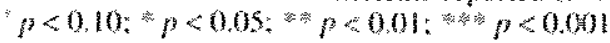

Hypotheses $2 a$ and $2 b$ predicted a nonlinear (inverted U-shaped and U-shaped, respectively) relationship between innovational slack and IPO value. The coefficient for the $R \& D$-slack squared term is negative and significant, providing support for hypothesis $2 \mathrm{a}$, and the coefficient for the patent-slack squared term interestingly is positive and significant, which is opposite to what we expected. The linear terms for both innovationalslack variables were significant. Hypothesis $3 \mathrm{a}$ and $3 \mathrm{~b}$ predicted an inverted U-shaped relationship between managerial slack and IPO value. The results show that contrary to our expectations, the coefficient for insider slack squared term is positive and significant. The squared term coefficient of industry-experience slack was negative but not significant. The number of insiders slack linear term was negative and significant while the linear term for experience slack was not significant.

Further, we performed additional analyses to evaluate whether the results indicate robust relationships in the data. First, we reran the same regression equations used to test the hypotheses with $25 \%$ of the sample randomly deleted from the data set. The results 
were identical to the ones presented in our model utilizing $100 \%$ of the data except for hypothesis 2 that lost some significance (from $p<0.001$ to $p<0.01$ ). Second, $50 \%$ of the sample were randomly deleted from our data set. This time, the model retained support for all hypotheses except hypothesis 2 that lost all support. Overall then, it is reasonable to suggest that our findings seem robust and stable. Further, our results show that they are not spurious but instead they reveal a distinct structure within the data that is supportive of our hypotheses.

\section{Discussion}

We found financial slack, specifically cash reserves, to be positively and significantly related to the capital raised through an IPO. The results suggest that financial slack may provide a signal to investors about the quality of the firm and its future performance potential. A strong financial position supports future growth because, as Penrose (1959) explained, a firm's future strategies are mainly determined by its current portfolio of resources, particularly by its financial resources. Additionally, firms with financial slack can be sending a signal about their ability to respond to shifting environmental demands (Cheng \& Kesner, 1997). Bromiley (1991) reasoned that financial slack provides firms with the ability to smooth over short-term disturbances in the environment and, thus, build and maintain competitive advantage. These findings are also interesting given the commonly held view that financial slack could imply the existence of excess resources that are not being used for productive purposes (Mishina et al. 2004) and that it could lead to inefficiency and nonoptimizing behavior (Bourgeois, 1981; Simon. 1957). However, we see it as a matter of context, where potential investors seem to perceive financial slack as a positive-given the high demands of undertaking an IPO-not a negative. Therefore, in the case of high-tech firms that are planning to undertake an IPO, a solid financial position seems extremely important to reduce the uncertainty surrounding the firm in the eyes of investors.

On the other hand, as predicted, working capital slack was negatively related to IPO value. This result reveals that investors disapprove of firms with high levels of working capital slack. Such a signal can indicate that these young, untested firms have too many accounts receivables, carry a lot of inventory and, therefore, are inefficient and/or risky. Not being able to collect on receivables could, arguably, be expected from many of these young firms. Small or new firms are seen as easy targets for tardy payers. Many of these high-tech industries can be characterized as being difficult to pioneer in, thus making it more difficult to sell the product once it is developed, and being high-tech, product complexity may require large numbers of expensive parts, thus increasing inventory costs and risk. Additionally, medical equipment or biotech industries are both industries that may have very high minimum-efficient scale, therefore making it difficult for these young companies that are trying to introduce new products into such an industry. Regardless of all these difficulties, slack in working capital denotes inefficiency and an increased risk of failure.

Innovational slack was found to be significantly related to IPO value. R\&D slack was found to have a negative coefficient (inverted-U shaped), while, contrary to expectations, patent slack was found to have a positive coefficient relationship with IPO value (U-shaped). The finding for R\&D slack is interesting insofar as it suggests that, up to a certain point, investors perceive R\&D slack positively. For high-tech firms that want to have an IPO, it seems safe to argue that above-average industry investments are expected. Investors want to see these frms investing more than their peers, which might signal high 
levels of commitment to innovation. Firms that are not committed, or might have CEOS that are not committed, will be extremely reluctant to have slack in R\&D at that stage. Even though R\&D expenditures have been linked to an increase in market value (Chauvin \& Hirschey, 1993; Doukas \& Switzer, 1992), it appears that there is an optimal amount. Large R\&D investments in IPO firms might signal high risk. For more established companies, above-industry-average investments in R\&D might be expected, but in the case of IPO firms-given the uncertainty surrounding $R \& D$ investments and the usefulness of the outcomes-such investments may be a red flag and indicate that innovations are still far from being ready for commercialization. In the case of patent slack, we found that investors prefer new firms to have either low amounts or high amounts of patent slack, reflecting preference for either using trade secrets or building patent fences. Thus, the key selling points for IPO firms is their innovation and their management, and innovation is best protected through trade secrets or by embracing the costs of patent defense.

We found that managerial slack is significantly related to IPO valuations. However, contrary to our prediction, the number of managers slack squared term was positively and significantly associated (U-shaped) with raising funds through an IPO. It appears that investors either do not like slack (a lean TMT is better) or they like a large team with spare capacity. What is surprising, but perhaps should not be given Penrose's (1959) arguments, is the final part of that curve, where investors value firms with high levels of managerial slack. We argued that the costs associated with having that many managers would affect an organization negatively. Investors though seem to feel that high levels of managerial slack might be an indication of managerial commitment to growth where these firms are accumulating the resources needed for such plans. Investors seem to be cautious of firms that have moderate levels of managerial slack and the potential for inefficiency. Firms that fall in the middle here might signal a lack of purpose since such moderate levels of managerial slack might not be sufficient for undertaking large growth initiatives, such as acquiring another firm (Brau \& Fawcett, 2006). Previous research shows that issuing firms try to enhance their image and attract investor attention by managing earnings before an IPO (Teoh et al., 1998), and typically startup firms are known to add managers just before IPO, in the hopes of raising additional funds and, perhaps, to ease investors' concerns (Zimmerman, 2008).

Experience slack was not significant. One possible conclusion here could be that investors do not perceive excess managerial experience of TMT members at the time of the IPO as important as we theorized they would. Because industry-specific managerial experience can be obtained in the labor market and deployed in firms in the same industry, its value added may be low, and investors may view a certain level of experience as sufficient to undertake any challenge they face. Another possible conclusion might have had to do with the way we measured experience slack. This we discuss further in the limitations and future directions section.

\section{Implications}

The study makes a number of contributions to the literature. It develops a causal logic for the impact of different forms of slack resources on IPO firm success. Also, we have introduced the concepts of innovational and managerial slack that capture an aspect of slack resources that has not been examined before, thereby extending our knowledge of organizational slack by moving beyond the traditional emphasis on financial slack. By examining all three (financial, innovation, and managerial), this work provides a more complete understanding of the effects of slack resources. George (2005) called for research to study slack in different contexts to help classify behavioral differences 
between these firms. He believed that this would lead to a refinement of the logic of the slack-performance relationship. By focusing on IPO firms, this research helps to address this call. We argue, and our results appear to indicate, that resources can act as signals of quality, thus extending signaling theory in the IPO literature.

Previous IPO-signaling research focused primarily on the external associations of a firm (e.g., underwriter reputation or VC backing) or firm-specific characteristics (e.g., firm size or TMT composition). Megginson and Weiss (1991) found that because VC backing provides financial resources and expertise to a firm, it signals quality to investors. Financial and innovational slack also provide valuable signals. Higgins and Gulati (2006) showed that TMT composition can signal legitimacy in terms of the ability of the TMT to fulfill critical roles, access resources, and attract endorsements from prestigious partners. As this work shows, also having the right numbers of managers also provides a signal for investors. Moderate levels. however, seem to send a negative signal to investors, possibly suggesting inefficiency or even window dressing. And high levels of slack seem to be perceived by investors as a sign that these firms have large growth aspirations possibly through acquisitions.

\section{Limitations and Future Directions}

Because this study included a range of firms from different industries, the results can reasonably be generalized to different time periods and other industries. But there is the possibility that the unique characteristics of high-tech firms influenced the results. A focus on less technology-intensive IPO firms, or firms in more stable industries, might reveal additional insights into the way organizational slack influences IPO valuations. Also, this study used secondary data: we relied on observable indicators, such as the number of managerial positions, to measure managerial-slack constructs that involve tacit, experiential knowledge. An in-depth study into the process mechanisms could explain the links between managerial slack and IPO value, and alternative methodologies, such as surveys, experiments, and simulations, may provide additional insights.

For future research, other forms of financial, innovational, and managerial slack deserve to be examined. For example, tapping into managerial experience through the number of positions is a logical approach, with precedent (e.g., Kor, 2003). Nevertheless, the way we measured this variable might have affected the results. Researchers still find numerous problems with identifying and quantifying specialized knowledge. For instance, it often only becomes obvious which knowledge was important for success long after the firm was established and has gone public. For example, with Apple, it appears that it was Steve Jobs's understanding of the humanization of technology that was important, rather than any specific technical knowledge. Also, given that we are dealing with slack resources, that means that we have to be able to quantify the knowledge either in absolute terms or relative to others in the field. Making that assessment requires being an expert in, or having access to someone who is an expert in, each manager's specialized knowledge. We see here a number of directions for future research. Some scholars might find it rewarding to investigate better ways of capturing this knowledge. Also, future research may address the question of if the value of past IPO experience is critical because entrepreneurial firms may avoid startup mistakes by hiring managers with this experience (Dyke, Fischer, \& Reuber, 1992). Or managers' experience in related industries perhaps could be valuable to young firms, as could their experience on the boards of other startups. 


\section{Concluding Remarks}

Much discussion has taken place in the management literature regarding the question of whether slack resources are beneficial or detrimental to the success of a firm (e.g., Bourgeois, 1981; Cheng \& Kesner, 1997; Cyert \& March, 1963/1992; Singh, 1986). Our work aimed to demonstrate the importance of slack resources in a different context. In short, we would like to reiterate that recognizing the effect of slack resources on IPO firm valuation is not only theoretically important but also practically significant. Our findings show that financial, managerial, and innovational slack provides signals to investors about the quality of the fim and its future performance potential.

\section{REFERENCES}

Akerlof, G.A. (1970). The market for "lemons": Quality uncertainty and the market mechanism. Oranterly Jounal of Eomomics, $84(3), 488-500$.

Amit, R. \& Schoemaker, PJ.H. (1993). Strategic assets and organizational rent. Strategic Momagement Joumal, $14(1), 33-46$.

Arend. R.J. (2003). A dyad-based analysis of new venture success: Comparing recent internet and non-intemet related IPOs. Jountal of Priwate Equity, 59(Winten), 59-71.

Arthurs. J.D., Busenitz, L.W. Hoskisson, R.E., \& Johnson, R.A. (2009). Signaling and intial public offerings: The use and impact of the lockup period. Jounal of Business Venturing, $24,360-372$.

Ashton. W.B. \& Sen, R.K. (1988). Using patent information in technology business planning. Reseawh Techology Managemen, $3 /(6), 42-46$.

Barry, C.B., Muscarella, C.J., Peavy, J.W.1., \& Vetsuypens, M.R. (1990). The role of venture capital in the creation of public companies: Evidence from the going-public process. Joumal of Finunial Economics. $272), 447-471$.

Beatty. R.P. (1989). Auditor reputation and the pricing of initial public offerings, Acomating Roview, 64(4), $693-709$.

Beatty, R.P. \& Ritter. J.R. (1986). Investment banking, reputation, and the underpricing of initial public offerings, Joumal of Financial Economics. $15(1 / 2), 213-232$.

Beatty, R.P. \& Zajac, E.J. (1994). Managerial incentives, monitoring, and risk bearing: A study of executive compensation, ownership, and board structure in intial public offerings. Administrative Science Qtarterly, $39(2) .313-335$.

Booth. J.R. \& Smith. R.L. II (1986). Capital rasing, underwriting, and the certificaton hypothesis. Jonmal of Financial Economics, $15(1 / 2), 261-281$.

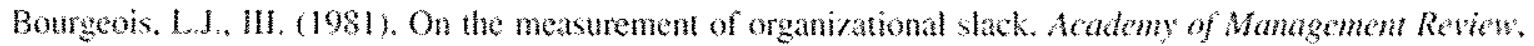
(6(1). 29-39.

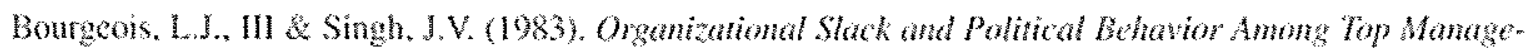
mon Teams. Paper presented at the Academy of Management Procedings.

Brat. J.C. Brown, R.A., \& Osteryoung, J. (2004). Do venture capitalists add value to small manufacturing firms? An empirical antlysis of venture and non-venture capital-bached intial public offerings, Joumal of Small Business Manogement, 42, 78-92. 
Brau, J.C. \& Fawcet, S.E. (2006). Initial public offerings: An analysis of theory and practice. Joumal of Finance, 61(1), 399-436.

Brav, A. \& Gompers, P.A. (2003). The role of lockups in initial public offerings. Review of Financial Studies, 16(1). $1-29$.

Brealey, R. \& Myers, S. (1996). Principles of eorporate finance. New York: MeGraw-Hill.

Bromiley, P. (1991). Testing a causal model of corporate risk taking and performance. Academy of Management Jommal, 34(1), 37-59.

Carpenter, M.A., Sanders, W.G. \& Gregersen, H.B. (2001). Bundling human capital with organizational contex: The impact of international assignment experience on multinational firm performance and CEO pay. Academy of Management Joumal, $44(3), 493-511$.

Carpenter. R.E. \& Petersen, B.C. (2002). Capital market imperfections, high-tech investment, and new equity financing. Efonomic Journal, $1 / 2(477)$, F54.

Carter, R. \& Manaster, S. (1990). Initial public offerings and underwriter reputation. Joumal of Finance. 45(4). 1045-1067.

Carter, R.B., Dark, F.H., \& Singh, A.K. (1998a). Boards of diretors: Size and composition and the effect on IPOS. Working paper, lowa State University.

Carter, R.B., Dark, F.H., \& Singh, A.K. (1998b). Underwriter reputation, intial returns, and the long-run performance of IPO stocks. Jommal of Finance. 53(1), 285-311.

Castanias, R.P. \& Helfat, C.E. (1991), Managerial resources and rents, Joumal of Management, 17(1), $155-171$.

Certo, S.T. (2003). Influencing initial public offering investors with prestige: Signaling with board structures. Academy of Managentent Review, 28(3), 432-446.

Certo, S.T., Covin, J.G., Daily, C.M. \& Dalton. D.R, (2001), Wealth and the effects of founder management among IPO-stage new ventures. Strategic Management Joumal, 22(6/7), 641-658.

Certo, S.T., Daily, C.M. \& Dalton. D.R. (2001). Signaling firm value through board structure: An investigation of initial public offerings. Entrepreneurship Theory and Practice, 26(2), 33-50.

Certo, S.T., Holcomb. T.R. \& Holmes. R.M. (2009). A synthesis of IPO research in management and entrepreneurship: Moving the agenda forward. Joumal of Managemen, 35(6), 1340-1378.

Chakravarthy, B.S. (1986). Measuring strategic performance. Strategic Mandgement Joumal, 7(5), 437-458.

Chatuvin, K.W. \& Hirschey, M. (1993). Advertising, R\&D expenditures and the market value of the firm. Financial Management, 22(4), 128-140.

Cheng, J.L.C. \& Kesner. I.F. (1997). Organizational slack and response to environmental shifts: The impact of resource allocation patterns. Joumal of Managenent, $23(1), 1-18$.

Comanor, W.S. (1965). Research and technical change in the pharmaceutical industry. The Revion of Economics and Statistics, 47, 182-190.

Cryer. J.D. \& Miller, R. (1991). Statistics for business: Data analysis and modeling. Boston: PWS-Kent.

Cyen, R.M. \& March, J.G. (1963/1992). A behatoral theory of the firm. Englewood Cliffs, NJ: Prentice-Hall.

Daily, C.M., Certo, S.T. \& Dalton. D.R. (2005). Investment bankers and IPO pricing: Does prospectus information matter? Joumal of Business Venturing. 20(1), 93-111. 
Daily, C.M., Certo, S.T., Dalton, D.R., \& Roengpitya, R. (2003). IPO underpricing: A meta-analysis and research synthesis. Entrepreneurship Theory and Practice, 27(3), 271-295.

DeCarolis. D.M. \& Deeds, D.L. (1999). The impact of stocks and flows of organizational knowledge on firm performance: An empirical investigation of the biotechnology industry. Strategic Managemen Jotmal, 20, $953-968$.

Deeds, D.L.. DeCarolis. D., \& Coombs, J.E. (1997). The impact of firm-specific capabilities on the amount of capital raised in an initial public offering: Evidence from the biotechnology industry. Joumal of Business Venturing. $12(1), 31-46$.

Deeds, D.L., DeCarolis, D., Coombs, J.E. (1998). Firm-specific resourees and wealth creation in high-technology ventures: Evidence from newly public biotechnology firms. Entreprenteurship Theory and Practice. $22(3), 55-56$.

Deeds, D.L., Mang, P.Y., \& Frandsen, M.L. (2004). The influence of firms" and industries' legitinacy on the flow of capitat into high-technology ventures. Strategic Organization, 2(1), 9-34.

Doukas, J. \& Swizer. L. (1992). The stock market's valuation of R\&D spending and market concentration. Joural of Economics and Business, $44(2) .95-114$.

Downes. D.H. \& Heinkel, R. (1982). Signaling and the valuation of unseasoned new issues. Jommat of Finatee. $37(1), 1-10$.

Dyke, L.S., Fischer, E.M., \& Reuber. A.R. (1992). An inter-industry examination of the impact of owner experience on tim performance. Jotumal of Small Business Management, 30(4), 72-88.

Eulie, JE, (1998). R\&D and global manufacturing performance. Mangement Science, 44(1), 1-11.

Filatother. I. \& Bishop, K. (2002). Board composition, share ownership, and "underpricing" of U.K. IPO firms. Strategic Management Journal, $23(10), 941$.

Finkelstein, S. \& Hambrick. D.C. (1996). Strategic leadership. St. Paul. MN: West Publishing Co.

Finkle, T.A. (1998), The relationship between boards of directors an inital public offerings in the biotechnology industry. Entrepreneurship Theory and Practice, 22(3), 5-29.

Fischer, H.M. \& Pollock, T.G. (2004). Eftects of social capital and power on surviving transformational change: The case of initial public offerings. Acatemy of Managemen Journal, 474), 463-481.

George. $\mathrm{G}$. (2005). Slack resources and the performance of privately held firms. Acateny of Management Joumal, $48(4), 661-676$.

Grabowski. H. \& Vernon, J. (1990). A new look at the returns and risks to phamaceutical R\&D. Management Sitence. $36.804-821$.

Grady, M.F. Alexander. J.I. Martin. D.L.. \& Merges, R.P. (1992). Patent law and rent dissipation; Commentaries. Vigima Law Rovem, 78, 305 381 .

Graves. S.B. \& Langowit. N.S. (1993). Innovative productivity and return to scale in the phamaceutical industry. Smategic Mandgomen Soumal, 14(8), 593-605.

Grenley, G.E. \& Oktemgil, M. (1998). A comparison of shok resotres in thigh and low perfoming Butish companies. Joumal of Managenent Sudies, 35(3), 377-398.

Greve, H.R. (2003). A behavional theory of R\&D expenditures and innovations: Evidence from shipbuilding. Academy of Managenent Journal, 46(6), 685-702. 
Gulati, R. \& Higgins, M.C. (2003). Which ties matter when? The contingent effects of interorganizational partnerships on IPO success. Strategic Management Joumal, 24(2), 127-144.

Hambrick, D.C. (1982). Environmental seanning and organizational strategy. Strategic Management Journal, $3(2), 159-174$.

Harris, D. \& Helfat, C. (1997). Speciticity of CEO human capital and compensation. Strategic Management Journal, (1986-1998), 18(11), 895-920.

Higgins, M.C. \& Gulati, R. (2006). Stacking the deck: The effects of top management backgrounds on investor decisions. Strategic Management Joumal, 27(1), 244-263.

Ibbotson, R.G. \& Jaffe, J.F. (1975). Hot issue markets. Joumal of Finance, 30(4), 1027-1042.

Ibbotson. R.G., Sindelar, J.L., \& Ritter, J.R. (1988). Initial public offerings. Joumal of Applied Corporate Finance. $1.37-45$.

Janney, J.J. \& Folta, T.B. (2003). Signaling through private equity placements and its impact on the valuation of biotechnology firms. Jounal of Business Venturing, $18(3), 361-380$.

Jelinek, M. \& Schoonhoven, C.B. (1990). The imoration marathon. Oxford, U.K.: Basil Blackwell, Lid.

Jensen. M.C. (1993). The modern industrial revolution, exit, and the failure of internal control systems. Jounal of Finance, 48(3), 831-880.

Kennedy, P. (1992). A guide to econometries. Cambridge, MA: MIT Press.

Khurshed, A. (2000). Discussion of does the presence of venture capitalists improve the survival profile of IPO firms". Journal of Business Finance \& Accounting, 27(9/10). 1177-1183.

Kor, Y.Y. (2003). Experience-based top management team competence and sustained growth. Organization Sience. 14(6). 707-719.

Kor, Y.Y. (2006). Direct and interaction effects of top management team and hoard compositions on R\&D investment strategy. Strategic Management Joumal, 27(11), 1081-1099.

Kor, Y.Y. \& Mahoney. J.T. (2000). Penrose's resource-based approach: The process and product of research creativity. Journal of Management Studies, 371), 109-138.

Kraatz, M.S. \& Zajac, E.J. (2001). How organizational resources affect strategic change and performance in turbulent environments: Theory and evidence. Orgamization Science, 12(5), 632-657.

Latham, S.F. \& Braun, M.R. (2008). The performance implications of financial slack during economic recession and recovery: Observations from the software industry (2001-2003). Joumal of Managerial lssues, $20(1), 30-50$.

Leibenstein, H. (1966). Allocative efficiency versus efficiency. American Economic Reviem, 56, 392-415,

Leibenstein, H. (1969). Organizational or frictional equilibria, X-efficiency, and the rate of innovation. Quarterly Journal of Eeonomics, $83(4), 600-623$.

Lester. R.H., Certo. S.T., Dalton, CM., Dalton, D.R., \& Cannella, A.J.A. (2006). Inital public offering investor valuations: An examination of top management team prestige and environmental uncertainty. Journal of Sinall Business Management, 44(1), 1-26.

Lev, B. (1969). Industry averages as targets for financial ratios. Joumal of Accoming Research, 7, 290-299.

Lin, T.H. (1996). The certification role of large block shareholders in initial public offerings: The case of venture capitalists. Quarterly Joumal of Business and Economics, 35t2), 55-65. 
Long. C. (2002). Patent signals. University of Chicago Law Reviow, 69, 625-679.

Loughran, T. \& Rilter, J. (2004). Why has IPO underpricing changed over time? Financial Management, $33(3) .5-37$.

Macgregor, D.G., Slovic. P. Dreman, D., \& Berry, P. (2000). Imagery, affect, and financial judgment. Joumal of Psychology and Financial Markets, $1,1040 \% 1110$.

Macmillan, 1.C. Kalow, D.M. \& Khoylian, R. (1989). Venture capitalists involvement in their investments: Extent and performance. Journal of Business Venturing, 4(1), $27-47$.

Mahoney. J.T. (1995). The management of resources and the resource of management. Journal of Business Researih, 33(2), 91-101.

Mahoney, J.T. \& Pandinn, J.R. (1992). The resource-based vicw within the converstion of stritegic man* agement. Stotegic Management Jommal (1956-1008), 13(5), 363-380.

Malewicki, D. \& Sivakumar, K. (2004). Patents and product development strategies: A model of antecedents and consequences of patent value. Ewopean Joumal of hnovation Mamagement, 7, 5-22.

March, J.G. \& Shapira, 2. (1987). Managerial perspectives on risk and risk taking. Momgenent Selence, $33(11), 1404-1418$.

McBain. M.L. \& Krause, D.S. (1989). Going public: The impact of insiders holdings on the price of initial public offerings. Jomal of Business Venturing, $4(6), 419-428$.

Megginson, W.L. E. Weiss, K.A. (1991). Venture capitalist centication in initial public offerings. Jomal of Finance. 46(3), 879-903.

Michaely, R. \& Shaw, W.H. (1994). The pricing of initin public offerings: Tests of adverse-selection and signaling theortes. Review of Financial Studies. 7(2), 279-319.

Mikkelson. W.H.. Parteh, M.M. \& Shah, K. (1997). Ownership and operating performance of companies that go public. Jomal of financial Ecomontics, 44(3), $281-307$.

Miller, D. Lant, T., Milliken, F. \& Korn, H. (1996). The evolution of strategte simplicity: Exploring two models of organizational adoption. Jomnal of Managentent, 22, 863,887.

Miller. K.D. \& Leiblein, M.J. (1996). Corponate risk-netum relations: Retums variability versus downside risk. Academy of Mamaement Joumal. 39(1), $91-122$.

Mishina, Y., Pollock. T.G., \& Porac, J.F. (2004). Are nore resources always better for growh? Resource stiekmess in market and product expansion. Strategic Management Jourhal. $25(12), 1179$ m 1197.

Moses, O.D. (1992). Organizational slack and risk-taking behaviour: Tests of product pricing strategy. Jomal of Organizational Change Managenem, 56, 38, 34.

Mudambi, R. \& Zimmerman. T.M. (2005). Cash chisis in newly public lnomet-based hims: An empirical antalysis. Joumal of Business Venming. 20.543-571.

Ndofor. H.A. \& Levitas, F. 2004). Signaling the strategic value of knowledge. Jommat of Managemon. $3015) .685-702$.

Nekon. T. (2003). The persistence of founder inhuence: Management, owmership, and periormane effects at initial puntic offering. Strategic Management Joumal. 248, 707-724.

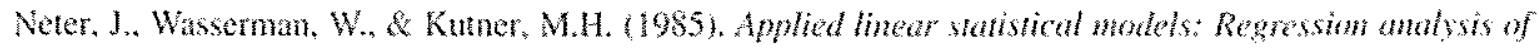
barken, and experinental design. Homewood, IL: Richard D. Irwin. 
Nohria, N. \& Gulati, R. (1995). What is the optimum amount of organizational slack? A study of the relationship between slack and innovation in multinational firms. Academy of Management Journal Best Papers Proceedings 1995, 32-36.

Nohria, N. \& Gulati, R. (1996). Is slack good or bad for innovation? Academy of Monagement Joumal, 39(5), 1245-1264.

Palmer, T.B. \& Wiseman, R.M. (1999). Decoupling risk taking from incone stream uncerainty: A holistic model of risk. Strategic Managenent Joumal. 20. 1037-1062.

Penrose, E. (1959). The theory of the grow th of the firm. New York: Oxford University Press.

Pollock, T.G., Chen, G. Jackson, E.M., \& Hambrick, D.C. (2010). How much prestige is enough? Assessing the value of multiple types of high-status affiliates for young firms. Joumal of Business Venturing, $25(1)$, $6-23$.

Prahalad, C.K. \& Bettis, R.A. (1986). The dominant logic: A new linkage between diversity and performance. Strategic Management Joumal, 7(6), 485-501.

PriceWaterhouse. (1995). The going public handbook. New York: Author.

Purnanandam. A.K. \& Swaminathan, B. (2004). Are IPOs really underpriced? Review of Financial Studies, 17. $811-8.48$.

Reed, R., Lemak, D.I. \& Hesser, W.A. (1997). Cleaning-up after the Cold War: Management and social issues. Academy of Management Review, 22, 614-642.

Reitzig, M. (2004). Improving patent valuations for management purposes: Validating new indicators by analysing application rationales. Research Policy, 33, 939-957.

Ritter, J.R. (1989). The "hot issue" market of 1980. Joumal of Business, 57(2), 215-240.

Ritter, J.R. (1998). Initial public offerings. Comtemporary Finance Digest, 2, 5-30.

Sanders, W.G. \& Boivic, S. (2004). Sorting things out: Valuation of new firms in uncertain markets. Strategic Monagement Joumal, 25(2), 167-186.

Scherer, FM. (1980). Industrial market stucture and economic performance. Boston: Houghton-Mifllin.

Simon, H.A. (1957). Administrative behavior. New York: Free Press.

Singh, J.V. (1986). Performance, slack, and risk taking in organizational decision making. Academy of Management Jommal, 29(3), 562-585.

Somaya, D. (2003). Strategic determinants of decisions not to sette patent litigations. Strategic Management Journal, 24, 17-38.

Spence, M. (1973). Job market signaling. Quartenly Jomnal of Economies, 87(3), 355-374.

Spender, J.C. (1989), Industry recipes: The Nature and sources of managerial jutgment. Oxford: Basil Blackwell.

Staw, B.M., Sandelands, L.E., \& Duton, J.E. (1981). Threat-rigidity effects in organizational behavior: A multilevel analysis. Administrative Science Quarterly, 26(4), 501-524.

Storrud-Barnes, S.F. Reed, R., \& Jessup, L.M. (2010). Uncertainty, risk preference, and new-venture strategies. Joumal of Strategy and Management, 3. 273m284. 
Stuar, T. \& Sorenson, O. (2003). The geography of opportunity: Spatial heterogeneity in founding rates and the performance of biotechnology firms. Research Policy, 32. 229-253.

Stuart, T.E. Hoang, H., \& Hybels, R.C. (1999), Interorganizational endorsements and the performanee of entrepreneurial ventures. Administrative Science Quarterty, 44(2), 315-349.

Tan, J. \& Peng. M.W. (2003). Organizational slack and firm performance during econonic transitions: Two studies from an emerging economy. Strategic Management Jothal. 24(13), 1249-1263.

Teoh, S.H., Welch, I., \& Wong. T.J. (1998). Eanings managenent and the long-run market performance of intial public offerings. Joumal of Finanes. $53(6)$, 1935-1974.

Titman. S. \& Trueman. B. (1986). Information quality and the valuation of new issues. Jommal of Accomming and Economics, $8(2), 159-172$.

Van de Ven. A.h.. Hudson, R., \& Schroder, D.M. (1984). Designing new business startups: Entrepreneurial, organizational, and ecological considerations. Joumal of Monagement, 10(1), 87-108.

Van der Eerden, C. \& Saelens, F.H. (1991). The use of science and technology indicators in strategic planning. Long Range Plaming, 24t3), 18-25.

Voss, G.B., Sirdeshmukh, D., \& Voss, Z.G. (2008). The effects of slack resources and environmental threat on product exploration and exploitation. Academy of Managemen Jotumal, 5/(1), 147-164.

Welboume. T.M. \& Andrews. A.O. (1996). Predicting the performance of initial public offerings: Should human resource management be in the equation? Academy of Management Joumat, 3944), 891-919.

Wiseman, R.M. \& Bromitey, P. (1996). Toward a model of risk in declining organizations: An empirical examination of risk, pertomance and decline. Orgatization Science, 7(5), 524-543.

Wright. M., Robbie, K., E Emew. C. (1997). Venture capialists and serial entrepreneurs. Joumal of Business Venturing. 12(3), 227-249.

Zimmerman, M.A. (2008). The influence of top management team heterogeneity on the capital raised through an initial public offering. Entrepreneurship Theory and Practice, 32(3), 391-414. 